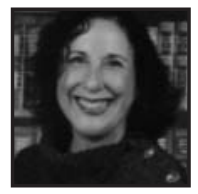

\title{
Spotting the Occasion for Poetry: An Invigorating Process of Finding Out by Finding In
}

\author{
Margaret Louise Dobson, McGill University
}

\section{ABSTRACT}

This essay illustrates how the spotting of a poem in a prose con/text can reveal essential lessons for research, teaching and learning. In describing the process of my inquiry, I demonstrate how writing a found poem unearths an otherwise hidden-or possibly forgotten-connection between finding poems and educating youth. To allow artful, heartfelt insights to emerge, we have only to learn how to "spot the occasion for poetry" (Sullivan, 2007).

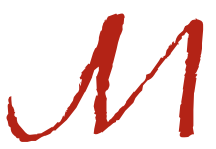

$y$ experimentation with the writing of poetry in the recent past has shown me that poems have a way of finding me rather than of me finding them. More often than not, a poem will appear as if by accident. More likely than not, a poem will shy away from intent. As a former school principal fresh from the fields of teaching and educational leadership, I am a newcomer to the writing of poetry and to the doctoral program in Integrated Studies in Education. After spending several recent years in school administration and in the writing of success plans, grants for funding, and letters to various constituents on behalf of other people, I wondered if I had an original thought left to call my own. To find out, I enrolled in a creative writing course at McGill University. Part way into the course, instead of the usual prose I was expecting, out popped little poems like newly sprouted wild violets in the summer's grass. Imbued with a reticent hue, the newlyborn-shy outcrop persistently insisted their way out of the blue and onto the pages of my weekly assignments. I loved them as only a mother can love. Shortly thereafter, on a quest of a similar nature, but with a different purpose, I enrolled as a doctoral student looking to find the hidden meaning of education within its purpose-driven 
mission. I came to talk back to the system. I wanted to find "somewhere / these children / (\& i ) / so very need / to go" (Prendergast, 2008). I came to question the imbalances of the dominantly utilitarian-instrumental worldview of education. I wanted to look beyond the prosaic facts of the matter and get to the poetic heart of the matter. What I am finding is a serendipitous coming together, a happy reunion, of poetry and education. Through the new-found perspective of poetic inquiry, I am discovering essential lessons for research, teaching and learning. I am beginning to find the answers I am looking for, and those answers are not where you would expect to find them. Finding out is an invigorating process of finding in.

It was in the spring term of the first year of my program that I first took Lynn Butler-Kisber's (2010a) course in Interpretive Inquiry. I had realized by now that the research I was interested in "doing" was not going to fall easily and neatly into conventional modes of academic research methodology. Poetic Inquiry was introduced in the course as only one of several possible arts-informed perspectives. I felt an immediate personal connection with the potential I sensed for letting new insights and new meanings emerge. For the course assignment, we were asked to work with the material in our course packs, and to write a found poem to demonstrate our newly acquired knowledge of poetic inquiry. As I began to think about my approach to the assignment, I decided to write a found poem from interview data that I had previously kept on hand for just such an exercise. As you will see shortly, I had a compelling "occasion" to change my mind on that decision. One of the crucial lessons to be learned by researchers working in the realm of poetic inquiry for the first time is not to expect preconceived plans to pan out.

While re-reading Anne Sullivan's essay, On Poetic Occasion in Inquiry: Concreteness, Voice, Ambiguity, Tension, and Associative Logic (Sullivan, 2007), I was struck once again by the poetic phenomenon I describe in my introduction. What I didn't expect was my strong emotional response to the content of the essay I was reading ostensibly to "learn about" poetic inquiry. The author was writing about "occasions for poetry," but I kept seeing, hearing and feeling "occasions for living"! Reading words in the essay such as "intuition," "embodiment," "voice," "emotion," "ambiguity," "associative logic," "open-endedness," "complexity," "mystery," "non-linearity," and "the circuitous and unresolved" IN A UNIVERSITY COURSE PACK was like gulping deep breaths of fresh air that I thought were long-gone from most public (and private) institutions. Like watching the negative of a photograph come to life in the developing solution of the dark room, I began to see the outlines and possibilities of a poetic re-presentation. It was the strong emotion evoked by the essay, and the intriguing parallels for education that I intuited that compelled me to work with 
this material, and no other. In short, I recognized an occasion for poetry. Finding and writing the poem became in and of itself an "act of inquiry that aims at making meaning of the world" (Brizuela, Stewart, Carrillo, \& Berger, 2000, p. xi).

\section{Being in and Doing the Work}

After my first reading of Sullivan's essay, I almost cried out loud. I felt that what was being reflected by the words "poetry" and "poems" was the very essence of life itself. Schools, in their ever-positivistic linear march towards progress, were squeezing out the very poetry from our lives, I thought. In sad, angry pen strokes of protest, I quickly jotted down my uncensored feelings and thoughts: "They (schools) have tried to take this from me, from you/Choked up by the Program, we have forgotten how to breathe." At the same time, I felt energized by the strong resonance I found in the work. Having inadvertently discovered an educational ally in Sullivan, my resolve to do something about it was renewed and strengthened. This sad $/ \mathrm{mad} / \mathrm{glad}$ cocktail was the powerfully intoxicating beginning of my process.

Thus began my inquiry, my "way of being in and doing the work from its inception to its conclusion" (Butler-Kisber, 2010b, p. 3). My aim was not only to understand how poetic inquiry could enhance qualitative research in general, but also to explore the intuitive connection I felt between finding occasions for poetry and research, teaching and learning. I was intrigued by the idea that in qualitative inquiry a found poem is discerned and written by the researcher, yes; but unlike generating my own poetry, in writing a found poem, I would have to allow another person's thinking, not my own, to "write" the poem. I acknowledged that I could reorganize the author's thought patterns into what I hoped would be poetry; but I could not touch or change a single word or the meaning of her words. I found myself required by unwritten "found poetic law" to remain true to the inherent voice of the author, and to convey that voice. Isn't that the real role of the educator? To listen for the student's "voice," discern the student's meaning, and draw that meaning forth? The parallel I found between writing found poetry and educating youth was exciting to me. In particular, I became interested (inter esse, Latin "to be inside") in finding out how the writing of a poem found in the con/text of Sullivan's essay might possibly contribute to the reinvigoration of an educational system that I perceive to be dying from a lack of oxygen. I resolved to go inside, find out how, and do something about it, with the renewed vigour propelled by my initial fiery etchings. 
I reread the essay, noting carefully the nuances of the words and lines that I had highlighted during my first reading. I trusted my initial impulses. Once again I delighted in the beauty of the found treasures. I turned them over and over in my mind and heart's eye. I contemplated their symbolic implications. Next, very tentatively at first, I started grouping the words and phrases according to their order in the essay. I listened closely for coherence. Once a rough idea of groupings or stanzas was sketched out in my notebook, I began the final look to "find" the whole poem. This meant more listening. This meant changing the sequence. I trusted my poetic instincts. I noticed how enjoyable and peaceful a process it was compared to some other churned-out academic exercises I had known in the past. Intuitive examination meant reading and refining, and again chipping away everything that didn't belong until I could begin to see the shape and hear the poem's human voice. I looked for the beautiful in the occasion because, as a researcher, I must confess, I came to the process with the absolute conviction that Beauty stands on her own merit, and needs no justification of purpose or utility. Sometimes just changing the position of a single line in a single stanza released an overall tone that was on its way to becoming beautiful. This was my unique way of finding out by finding in. "There is no template or prescribed approach for creating found poetry" (Butler-Kisber, 2010b, p. 85).

The following poem was written entirely from the text of Anne Sullivan's essay, as described above. No words or phrases have been changed, only the order of the words and phrases have been reconfigured according to the inner "dictates" of the found poem. It is my wishful thinking that the poem may come even close to conveying the essential, life-affirming lessons about research, teaching and learning that I found in Sullivan's essay.

\section{An Occasion for Poetry}

Learning to spot the occasion for poetry

Is learning to see the sculpture

That is already in the stone

Then chipping away everything

That is not David

Poems hide.

What we have to do

Is live in a way that lets us find them

I am not going to get straight to the point 
I want to examine the intuitive

Without reasoning towards it

Occasions for poetry

Must be concrete, straightforward

The everyday sensory stuff

Getting the poem into the body

Renders the "lived experience"

Of wheat fields, flocks and sheep

Resonant with powerful feelings

Recollected in tranquility

Bearing sensory information

Charged with emotion

Highlighted in the colours of idiosyncrasy

The human voice

May be the true occasion for their existence

Possibility wide open

No meaning trapped, enclosed, contained

The everyday and unresolved

Circuitous thoughts of you and me

Rife with complexity and mystery

May be found occasions for poetry

Word connecting with word

Line with line

As with the spider web

Touch it at any part

And the whole structure responds

In associated logic

A nexus of tensions

Integral and essential

Avoiding the habit of conclusion

I would have to unlearn tidy linearity

I would need to make leaps

As the mind leaps

As impulses fire across synapses 
With unexpected turns

And surprising connections

The doors and windows are open

You decide

\section{Reflections on the Process}

How differently we might approach research, teaching and learning if we were to seriously consider the premise that education is the sacred act of looking for the "David" within every student. My poetic inquiry, through the perspective of found poetry, has reminded me of the wealth of poetic occasions lying dormant (but still alive, amazingly enough!) under the hardened surface of any prosaic undertaking such as schooling. Once the source of energy and interest is found, or, as in my experience, once the poem finds me, the well is primed. The rest of the procedure flows easily, relatively speaking, because the creative process is at the source, not just my limited intellect all on its own. For example, at the very moment when my intuition was allowed to become engaged in the process of inquiry because I didn't dismiss outright the vision of a found poem emerging from the essay and not from the formerly intended interview data, I discovered that poetry was in the making. From the experience of poetic inquiry, I see an undeniable connection between poetry and education. Education (e-duco, e-ducare, Latin, to draw forth from within), not schooling (training from the outside in), is in the offing! As educators newly oriented to finding the David within, we would no longer be required to assume schooling's arduous and unreasonable task of making some/thing of ourselves and of our students. We would have only to develop and/or strengthen the necessary "perceptivity" (Barone \& Eisner, 1997). To look behind appearances, and to discern beneath surfaces, we would need to relearn how to perceive interior landscapes in a way that would allow ourselves and others to emerge as the some/one we, and they, really are. Like a found David emerging from the surrounding stone, there I am; there you are!

"An Occasion for Poetry" has taught me that we must make room for unexpected outcomes if we are truly to "make meaning of our world" (op. cit.). The unlearning of the habits of tidy, predictable linear thinking, so well ingrained through schooling, will be the biggest challenge faced by arts-informed educators as we move away from the prosaic "mould-by-concepts," "paint-by-numbers" approach to schooling and begin to lean towards the artistic "emergent" approach of education. The integral 
combination of the poem's content and process of an arts-informed inquiry has arrived at the same open-ended conclusion. This fact is a significant find in and of itself.

\section{Emerging Possibilities}

No doubt there will be a strong backlash to a more artistic orientation in education. Too much of our current worldview is deeply invested in the manufacturing of a socio-political identity dependent upon, and addicted to, the assumption of outer concepts, and the consumption of outer resources for there to be an easy transition. There is sure to be a fight. Poetic inquiry through found poetry has been an invaluable perspective for putting me in touch with my own intuition in a way that is unmistakably real. More than just putting me in touch theoretically with a concept about intuition, the inquiry has actually dared me to find, respect and follow my intuition as a valued partner of my intellect. I learned, in practice, to trust my intuition, and by so doing, to let the creative process unfold to where the poem "wanted" to go, not to where my intellect "planned" to take it. Transformation of any real magnitude is unpredictable. It comes out of the blue. It has its own agenda and time frame. Just as in poetic inquiry, you don't know where you're going until you get there. Ultimately, this particular inquiry led me to an original poem, created through an original experience, and based on a deep resonance and appreciation of a colleague's original essay. Novice researchers such as me who are experimenting with arts-informed methodologies for the first time are finding not just found poems, but a sound footing in an arts-informed practice. We may be amateur artists; but we will not be easy pushovers in the struggle for a legitimate say in the education of our youth!

\section{References}

Barone, T., \& Eisner, E. (1997). Arts-based educational research. Complementary methods for research in education, 2nd edition. $\mathrm{R}$. Jaeger, ed. Washington, DC: AERA.

Brizuela, J.P., Stewart, R. G., Carrillo, R.G., \& Berger, J. G. (2000). (Eds.) Introduction. Acts of inquiry in qualitative research. Harvard Educational Review, Reprint Series no. 34, xi-xxii.
Butler-Kisber, L. (2010a). EDEC 707-001 Interpretive Inquiry, McGill University. Montreal, QC: COPIBEC (HBSP).

Butler-Kisber, L. (2010b). Qualitative inquiry: Thematic, narrative and arts-informed perspectives. London: SAGE. 
Prendergast, M. (2008). UNESCO world conference on arts education: A poetic review. LEARNing Landscapes, 2(1), 39.
Sullivan, A. (2007). On poetic occasion in inquiry: Concreteness, voice, ambiguity, tension, and associative logic (This essay was originally delivered as a talk at the 1st Symposium on Poetic Inquiry, UBC, Vancouver, October 2007).

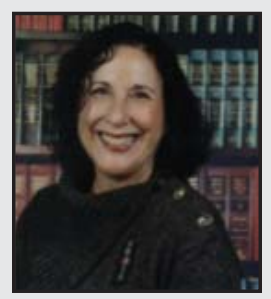

Margaret Louise Dobson is a PhD student in the Faculty of Education of McGill University. Prior to entering the doctoral program, she taught high-school French and English in Ontario and Quebec. Most recently she assumed leadership responsibilities in both elementary and secondary schools of the English Montreal School Board. Her doctoral studies focus on the role of thinking (as distinct from knowing) in the reinvigoration of education. She has published in the forthcoming anthology, The Heart of Wisdom: Life Writing as Empathetic Inquiry. 